\title{
Loading of Oxidizable Transmitters into Secretory Vesicles Permits Carbon-Fiber Amperometry
}

\author{
Kyong-Tai Kim, ${ }^{1,2}$ Duk-Su Koh, ${ }^{1}$ and Bertil Hille ${ }^{1}$ \\ ${ }^{1}$ Department of Physiology and Biophysics, University of Washington, Seattle, Washington 98195-7290, and \\ 'Department of Life Science, Division of Molecular and Life Science, Pohang University of Science and Technology, \\ Pohang, Korea
}

Carbon-fiber amperometry detects oxidizable molecules released by exocytosis. We extended this electrochemical technique to cells that do not normally secrete oxidizable transmitters. We incubated AtT-20 cells, pituitary gonadotropes, cultured cerebellar granule cells, and yeast with high concentrations of dopamine (DA) and observed spontaneous and evoked quantal release of DA by amperometry. The rate of detectable spontaneous amperometric events was used as a measure of loading in AtT-20 cells. With 70 mm DA in the bath, loading was complete within $40 \mathrm{~min}$. Cytoplasmic accumulation preceded vesicular loading. Loading decreased proportionally as the bath DA concentration was lowered. Loading rates were similar at 37 and $25^{\circ} \mathrm{C}$ and much slower at $15^{\circ} \mathrm{C}$. Loading was blocked by bafilomycin $A_{1}$, a proton pump inhibitor, but not by bupropion, an inhibitor of the plasma membrane DA transporter. Other cells were tested. Spontaneous quantal events became more frequent and evoked events became larger and more frequent when PC12 cells were loaded with DA. Fluidphase loading of neurons by short stimulation in DA solutions seemed selective for the synaptic vesicles. Thus, many cell types can be loaded with DA to study spontaneous and evoked exocytosis. The amine molecules enter these cells passively and may become concentrated in acidic vesicles by protonation.

Key words: secretion; exocytosis; amperometry; carbon fiber; vesicle; gonadotrope; granule cell; dopamine
Eukaryotic cells have vesicular traffic to the plasma membrane. Some vesicles from the Golgi apparatus are secreted constitutively, whereas regulated secretion of prepackaged neurotransmitters and hormones depends on physiological cues. We wanted to apply the very sensitive and noninvasive method of amperometry (Chien et al., 1990; Leszczyszyn et al., 1991; Chow and von Rüden, 1995) to studies of vesicular traffic in a variety of cells. Amperometry permits detection of secreted molecules with millisecond time resolution by oxidation at a carbon-fiber electrode (Wightman et al., 1991; Chow et al., 1992; Alvarez de Toledo et al., 1993). It resolves single-vesicle release events. However, amperometry can be used only if cells release an oxidizable transmitter.

Here we apply amperometry to other cell types by loading oxidizable molecules in their vesicles (Zhou and Misler, 1996; Billiard et al., 1997; Koh et al., 2000). We find optimal conditions for loading and investigate the loading mechanism.

\section{MATERIALS AND METHODS}

Cell culture. AtT-20 cells were maintained in DMEM supplemented with $10 \%$ calf serum and $1 \%$ antibiotics. PC12 cells were cultured in RPMI 1640 medium containing $10 \%$ horse serum, $5 \%$ bovine calf serum, and $1 \%$ antibiotics. Animals were killed by decapitation. Anterior pituitary gonadotropes were isolated and identified with the reverse hemolyticplaque assay (Billiard et al., 1997). Cerebellar granule neurons were

\footnotetext{
Received April 11, 2000; revised July 24, 2000; accepted July 25, 2000.
}

This work was supported by National Institutes of Health Grants AR 17803 and cooperative agreement U54 HD12629 as part of the Specialized Cooperative Centers Program in Reproductive Research. K.T.K received scholarship from the Seoam Foundation. We thank D. Anderson and L. Miller for technical assistance and Drs. J. H. Joo and U. Namgung for providing yeast, PC12, and cerebellar granule cells. Dr. D. F. Babcock kindly investigated spectroscopic properties of 5,7-DHT. We also thank Drs. D. F. Babcock and M. S. Shapiro for critically reading this manuscript.

Correspondence should be addressed to Bertil Hille, Department of Physiology and Biophysics, G-424 Health Sciences Building, University of Washington, Box 357290, Seattle, WA 98195-7290. E-mail: hille@u.washington.edu.

Copyright (C) 2000 Society for Neuroscience $0270-6474 / 00 / 200001-05 \$ 15.00 / 0$ cultured from Sprague Dawley rats of postnatal day 7 on poly-L-lysinecoated glass coverslips (Schulz et al., 1996). Neurons were grown in basal Eagle's medium supplemented with $10 \%$ bovine calf serum, $25 \mathrm{~mm} \mathrm{KCl,}$ and $2 \mathrm{~mm}$ glutamine and used 6-8 d after plating. The cell wall of yeast (Saccharomyces cerevisiae) was removed by treating with zymolase (2 $\mathrm{mg} / \mathrm{ml}$ ) in a high osmolar $\mathrm{Na}^{+}$-rich saline before incubation in dopamine loading solution (Dunn and Wobbe, 1997). Spheroplasts attached to a glass coverslip coated with poly-L-lysine were used for amperometric measurements.

Materials. Stock solutions of bafilomycin $\mathrm{A}_{1}(1 \mu \mathrm{M})$ and ionomycin (5 $\mathrm{mm}$ ) were made in dimethylsulfoxide. Heat-inactivated bovine calf and horse sera, DMEM, RPMI 1640, basal Eagle's medium, penicillin V, and streptomycin were obtained from Life Technologies (Grand Island, NY), ionomycin from Calbiochem (La Jolla, CA), GnRH from Peninsula Laboratories (San Carlos, NY), and indo-1 AM from Molecular Probes (Eugene, OR). Bupropion hydrochloride, dopamine hydrochloride (DA), $\mathrm{N}$-methyldopamine hydrochloride, 3,4-dihydroxybenzylamine hydrochloride, serotonin hydrochloride, and 5,7-dihydroxytryptamine creatinine sulfate were from Research Biochemicals (Natick, MA). 3-O-methyldopamine hydrochloride, 1(2-methoxyphenyl)piperazine hydrochloride, and tyramine hydrochloride were from Fisher-Acros (Houston, TX). Glutamine, zymolase, bafilomycin $A_{1}$, and all other chemicals were from Sigma (St. Louis, MO).

Loading of exogenous monoamines. Cells were incubated for varying times in solution containing (in $\mathrm{mM}$ ): $70 \mathrm{DA}$, serotonin, or other DA analogs, $68 \mathrm{NaCl}, 2.5 \mathrm{KCl}, 2 \mathrm{CaCl}_{2}, 1 \mathrm{MgCl}_{2}, 10 \mathrm{D}$-glucose, and 10 HEPES, $\mathrm{pH} 7.3$ with $\mathrm{NaOH}$, at room temperature unless otherwise indicated. For concentrations of $\mathrm{DA}<70 \mathrm{~mm}, \mathrm{NaCl}$ was added to keep the osmolarity of solution constant.

This article is published in The Journal of Neuroscience, Rapid Communications Section, which publishes brief, peerreviewed papers online, not in print. Rapid Communications are posted online approximately one month earlier than they would appear if printed. They are listed in the Table of Contents of the next open issue of JNeurosci. Cite this article as: JNeurosci, 2000, 20:RC101 (1-5). The publication date is the date of posting online at www.jneurosci.org.

http://www.jneurosci.org/cgi/content/full/4595 
Amperometric measurement. Recordings were performed at room temperature in amine-free solution containing (in $\mathrm{mM}$ ): $137.5 \mathrm{NaCl}, 2.5 \mathrm{KCl}$, $2 \mathrm{CaCl}_{2}, 1 \mathrm{MgCl}_{2}, 10 \mathrm{D}$-glucose, and $10 \mathrm{HEPES}, \mathrm{pH} 7.3$ by NaOH. A carbon-fiber $(11 \mu \mathrm{m})$ electrode (Koh and Hille, 1999) polarized to either +400 or $+600 \mathrm{mV}$ was placed gently touching an individual cell. A local perfusion device changed solutions within 2 sec. Values are presented as mean \pm SEM. The cutoff filter frequency was $100 \mathrm{~Hz}$ unless otherwise noted.

Single-cell photometry. Intracellular free $\mathrm{Ca}^{2+}\left(\left[\mathrm{Ca}^{2+}\right]_{\mathrm{i}}\right)$ was measured in PC12 cells loaded with the $\mathrm{Ca}^{2+}$ indicator dye indo-1 by incubation with $1 \mu \mathrm{M}$ indo-1 AM for $30 \mathrm{~min}$ at room temperature (Babcock et al., 1997). The dye was excited at $365 \mathrm{~nm}$, and the fluorescence was measured at $405\left(F_{405}\right)$ and $500 \mathrm{~nm}\left(F_{500}\right)$. The background with no cells in the field was subtracted. Fluorescence measurements are reported as the ratio $F_{405} / F_{500}$, without absolute calibration for $\left[\mathrm{Ca}^{2+}\right]_{i}$

The rate of entry of 5,7-dihydroxytryptamine (5,7-DHT) into AtT-20 cells was assessed from fluorescence at $405 \mathrm{~nm}$. The AtT-20 cells were incubated with $35 \mathrm{~mm}$ 5,7-DHT for different times and washed with external saline solution for $2 \mathrm{~min}$. Single-cell fluorescence at $405 \mathrm{~nm}$ $\left(F_{405}\right)$ was then measured for $3 \mathrm{~min}$.

\section{RESULTS}

\section{Time course of DA loading}

To develop practical loading conditions, we used the mouse AtT-20 cell line (Gumbiner and Kelly, 1981). No amperometric signals were detected without DA loading (Fig. $1 A$ ). After a total of $30 \mathrm{~min}$ incubation with $70 \mathrm{~mm}$ DA, the same cell gave many amperometric spikes representing quantal release of oxidizable molecules (Fig. 1A). When single cells were loaded in additive 5 min episodes, the mean amplitude of events grew progressively, but the shape of the amperometric signal was relatively invariant (Fig. $1 B$ ). Figure $1 C$ shows the time course. The mean number of detectable amperometric spikes increased with incubation time after an initial delay of $\sim 5 \mathrm{~min}$, reaching half maximal at $14 \mathrm{~min}$ and was near maximal by $35 \mathrm{~min}$. At the same time, the mean number of oxidizable molecules per quantal event (integral of quantal current) grew almost linearly (triangles). This suggests that vesicles are filling throughout the $35 \mathrm{~min}$ of loading, but after 20 min most vesicles have enough DA to be above our detection threshold. Even after $30 \mathrm{~min}$, the wide range of amplitudes (and integrals) of amperometric events suggested considerable microheterogeneity of the vesicle populations (Fig. $1 A$ ).

Two sets of measurements suggested that DA accumulates initially in the cytoplasm and then can enter vesicles. First, cytoplasmic DA was assessed by piercing individual cells with a glass micropipette and measuring the amount of DA released by integrating the large, slow amperometric currents that followed. Second, we monitored cytoplasmic accumulation of the fluorescence of 5,7-DHT. This analog of 5-hydroxytrypamine (serotonin) was strongly fluorescent at $\mathrm{pH} 7.2$ but not at a $\mathrm{pH}$ of $\leq 6.5$ (D. F. Babcock, personal communication). Thus, increases in fluorescence indicate accumulation of 5,7-DHT in cytoplasm not in acidic compartments such as secretory vesicles. The time course of cytoplasmic loading showed no delay and half times of 6 min ( $n=7-21$ cells for DA loadings $)$ and $9 \min (n=10-14$ cells for 5,7-DHT loadings) by these two methods.

We further asked if AtT-20 cells can be loaded multiple times. Three sets of cells were simultaneously incubated in DAcontaining solution for $40 \mathrm{~min}$. One set of cells was measured with amperometry directly after loading, and the rate of detectable exocytosis was $42 \pm 12$ events $/ 3 \mathrm{~min}(n=8)$. The other two sets of cells were transferred to DA-free culture medium and incubated for $6 \mathrm{hr}$ at $37^{\circ} \mathrm{C}$. The rate of exocytosis detected using the second sets of cells was reduced to $2 \pm 1$ events $/ 3 \min (n=6)$, presumably by continuous exocytotic loss of DA during the $6 \mathrm{hr}$ incubation. The third set of cells was loaded with DA a second time. They redeveloped a high detectable exocytosis rate, $41 \pm 6$ events/3 min $(n=10)$. The once- or twice-loaded AtT-20 cells were intensively washed with DA-free culture medium and returned to the incubator for $2 \mathrm{~d}$. They proliferated to a similar cell

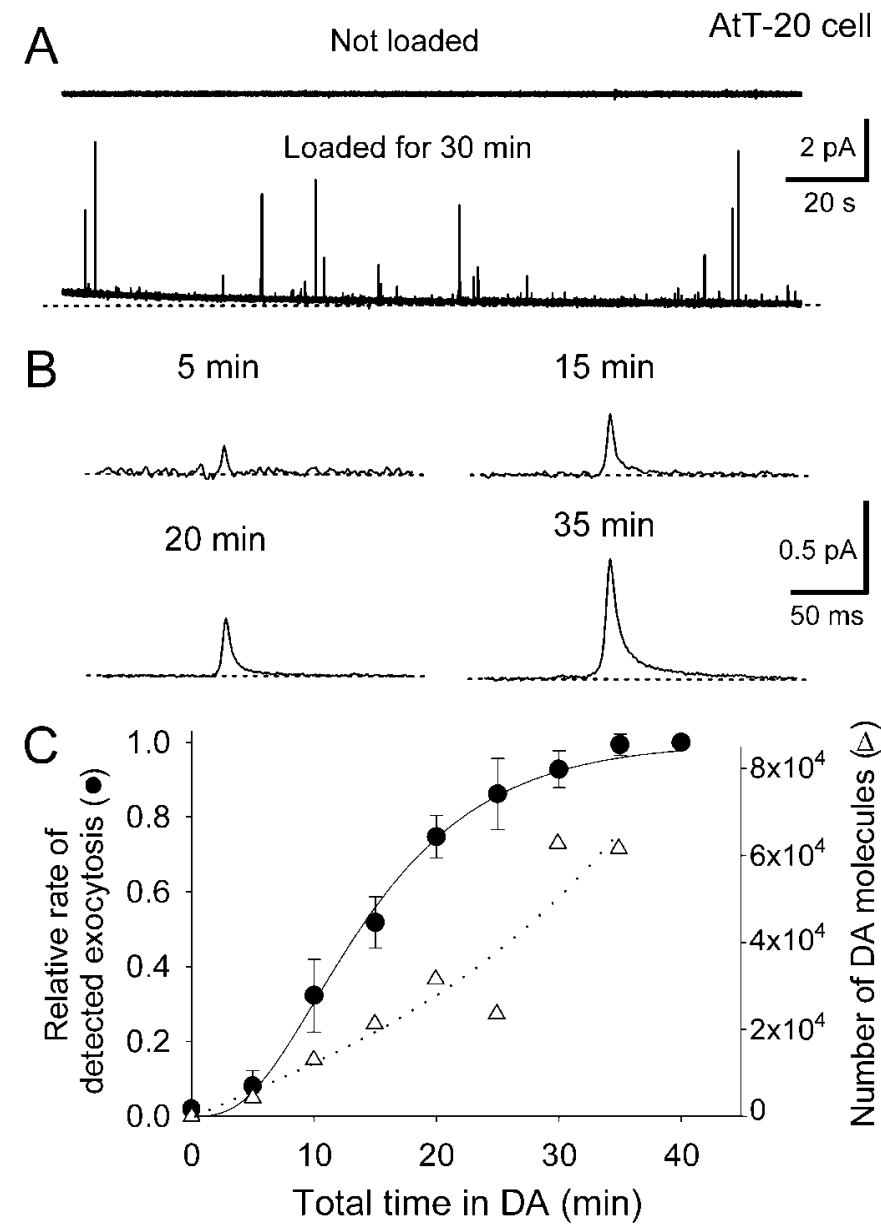

Figure 1. Long incubation with DA allows amperometric detection of exocytosis in AtT-20 cells. $A$, Amperometric signals from the same single cell recorded before (top trace) and after loading for $30 \mathrm{~min}$ at room temperature (bottom trace). Slow final washout of residual submicromolar DA near the cellular surface caused the slight decline of the baseline. $B$, Averaged waveforms of amperometric spikes in the same cell as $A$ after loading for different times. All detected events were aligned and averaged. $C$, Circles, Averaged time course of loading at room temperature. In each experiment a single cell was loaded with $70 \mathrm{~mm}$ DA solution in repeated 5 min episodes interleaved with 5 min episodes in DA-free solution using a local perfusion system. Recordings were made for $3 \mathrm{~min}$ in the DA-free solution after a $2 \mathrm{~min}$ wash. The carbon-fiber electrode was not moved during the experiment. Relative rate of exocytosis was measured as the number amperometric events relative to that with $40 \mathrm{~min}$ incubation. Each value is the mean \pm SEM for seven or eight cells. Data points are connected by smooth lines. Triangles, Time course of number of the DA molecules calculated from the integral (total charge) of averaged amperometric currents as shown in $B$.

density as untreated cells, indicating that DA loading was not deleterious for cell survival.

\section{Effects of concentration and temperature}

We explored loading under other conditions. The number of detectable secretory events increased proportionally after $1 \mathrm{hr}$ exposures to $0.07,0.7,7$, and $70 \mathrm{~mm} \mathrm{DA}$ (Fig. $2 A$ ). Lengthening the incubation from $1 \mathrm{hr}$ to $4 \mathrm{hr}$ doubled the number of detectable events with $7 \mathrm{~mm}$ DA to $\sim 33 \pm 5 \%(n=22)$ of the number with $70 \mathrm{~mm}$. Evidently a steep DA concentration gradient yields the best loading. For incubations with $70 \mathrm{~mm}$ DA, loading at $37^{\circ} \mathrm{C}$ was not statistically different from loading at $25^{\circ} \mathrm{C}$, the relative exocytosis being $134 \pm 13 \%(n=35-46 ; p=0.15$; Student's $t$ test $)$ for a 20 min incubation (Fig. $2 B)$ and $89 \pm 8 \%(n=20-37 ; p=$ 0.40 ) for a $30 \mathrm{~min}$ incubation. At $15^{\circ} \mathrm{C}$ loading was much reduced (Fig. 2B). 

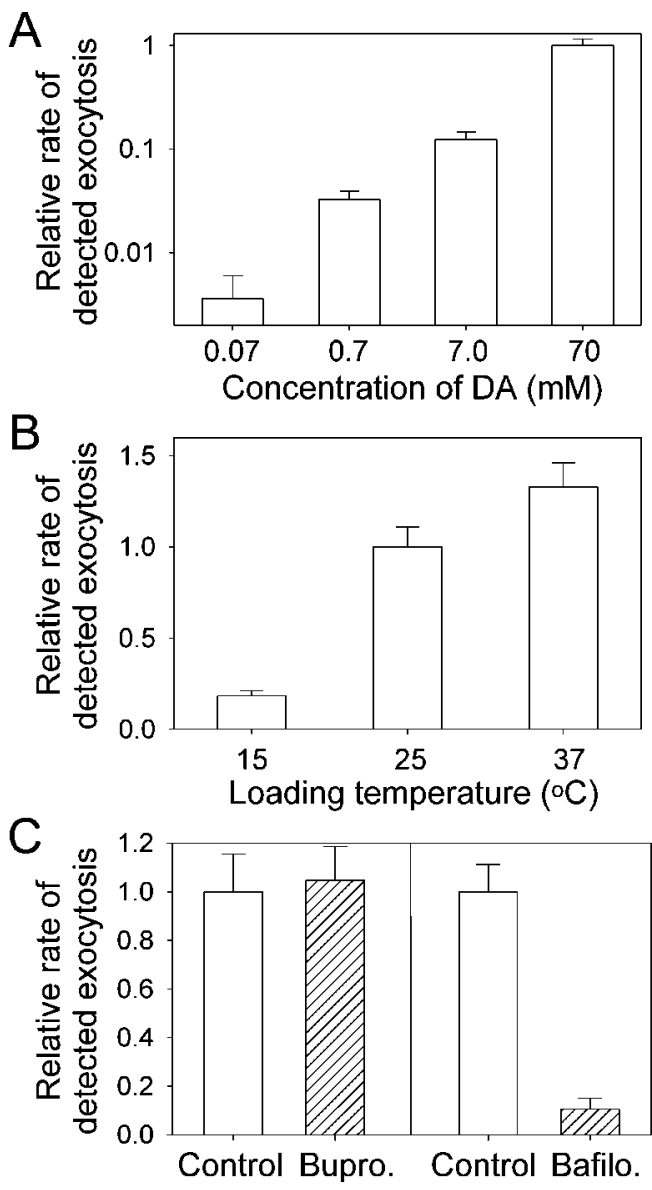

Figure 2. Properties of DA loading in AtT-20 cells. Relative exocytosis is the number of amperometric events detected in $3 \mathrm{~min}$. $A$, Loading with the indicated concentrations of DA at room temperature for $1 \mathrm{hr}$. Relative exocytosis rates normalized to $70 \mathrm{~mm}$ were $0.004 \pm 0.002,0.03 \pm 0.01$, $0.12 \pm 0.02$, and $1.00 \pm 0.15$ for $0.07,0.7,7$, and $70 \mathrm{mM}$, respectively $(n=$ $10-15)$. Note semilogarithmic axis. $B$, Cells were incubated with $70 \mathrm{~mm}$ DA at the indicated temperatures for $20 \mathrm{~min}$. Relative exocytosis rates normalized to $25^{\circ} \mathrm{C}$ were $0.19 \pm 0.03,1.00 \pm 0.11,1.34 \pm 0.13$, for 15,25 , and $37^{\circ} \mathrm{C}$, respectively $(n=35-46)$. C, Left , Cells were incubated with 30 mM DA at $37^{\circ} \mathrm{C}$ for $30 \mathrm{~min}$, in the absence (Control) or presence of $10 \mathrm{~mm}$ bupropion (Bupro.) $(n=20-21)$. Right, Cells were pretreated with dimethylsulfoxide vehicle (Control) or $0.5 \mu \mathrm{M}$ bafilomycin $\mathrm{A}_{1}$ (Bafilo.) at $37^{\circ} \mathrm{C}$ for $1 \mathrm{hr}$ and then incubated with $70 \mathrm{~mm}$ DA in the absence or presence of bafilomycin $\mathrm{A}_{1}(n=14-15)$.

\section{The mechanism of loading}

Cells were treated during loading with bupropion, an inhibitor of the plasma membrane DA transporter (Suaud-Chagny et al., 1995), or bafilomycin $A_{1}$, an inhibitor of the vacuolar-type $\mathrm{H}^{+}$ATPase (Bowman et al., 1988). Bupropion was tested at a concentration 50,000-fold higher than the reported half-maximal inhibitory concentration (0.19 $\mu \mathrm{M}$; Eshleman et al., 1994) to preclude possible competition (Dersch et al., 1994) from the high DA concentration in the loading solution. Nevertheless, bupropion $(10 \mathrm{~mm})$ did not have any inhibitory effect on the loading with 30 mm DA (Fig. $2 C$ ). On the other hand, bafilomycin $\mathrm{A}_{1}(500$ nм) almost abolished vesicular loading with $70 \mathrm{~mm}$ DA (Fig. 2C). Cytoplasmic accumulation of DA measured by breaking cells was not inhibited by bafilomycin $A_{1}$ (data not shown). Evidently monoamines at sufficient concentration will enter cells without mediation of specific transporters but then require a proton gradient to be concentrated in vesicles.

We found amperometric spikes similar to those with DA in cells incubated with two related molecules. Spikes were detected from AtT-20 and PC12 cells loaded in $30 \mathrm{~mm} n$-methyldopamine

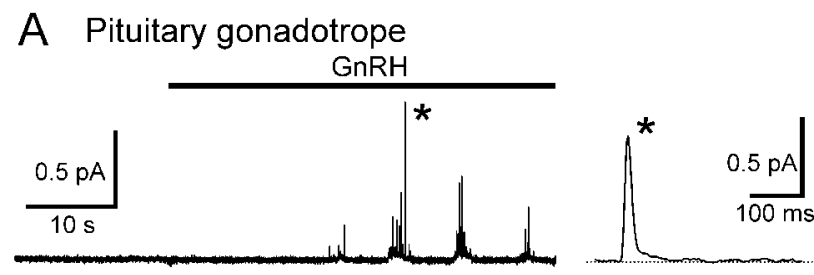

B Cerebellar granule cells

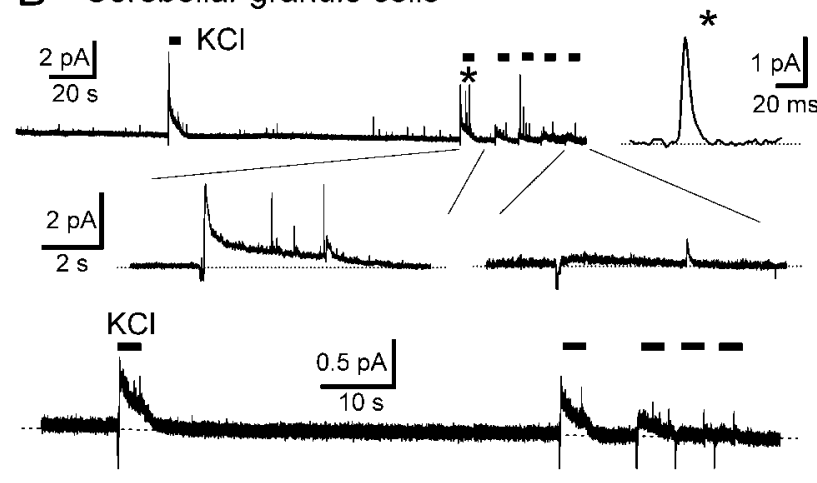

C Yeast spheroplast

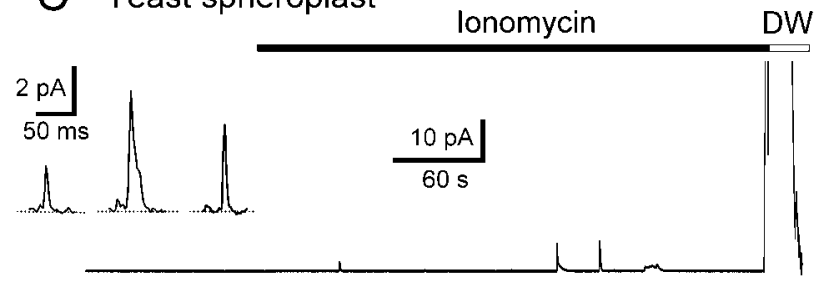

Figure 3. Loading of other cells with DA. A, Amperometric currents from an identified rat pituitary gonadotrope loaded with $70 \mathrm{~mm}$ DA for 40 min. The cell was stimulated with $10 \mathrm{~nm} \mathrm{GnRH}$ as indicated. One quantal event indicated by an asterisk is illustrated at faster time resolution. Filter frequency: $50 \mathrm{~Hz}$. $B$, Two methods for loading cerebellar granule cells. Top trace, Loading with $18 \mathrm{~mm} \mathrm{DA}$ for $50 \mathrm{~min}$. A $\mathrm{K}^{+}$rich-solution $(70$ mM) was applied for the times indicated by bars. Middle trace, Events indicated by lines are shown at expanded time scale. Bottom trace, Cells were preincubated for only $120 \mathrm{sec}$ with $70 \mathrm{~mm} \mathrm{DA}$ in a $70 \mathrm{~mm} \mathrm{KCl}$ depolarizing solution (data not shown) and then tested with $3 \mathrm{sec} \mathrm{KCl}$ depolarizations for exocytosis. $C$, Yeast spheroplasts loaded with $70 \mathrm{~mm}$ DA for $40 \mathrm{~min}$. A spheroplast was treated with $5 \mu \mathrm{M}$ ionomycin as indicated to induce $\mathrm{Ca}^{2+}$ influx into cytoplasm and then with distilled water $(D W)$ to trigger hypotonic cell lysis. Several quantal events from another yeast spheroplast are shown on an expanded time scale.

or 3,4-dihydroxybenzylamine, but they were not detected with 3-O-methyldopamine, 1-(2-methoxyphenyl)piperazine, or tyramine. All compounds reached the cytoplasm because in each case a large amperometric signal was detected when cells were ruptured. The results imply some specificity to loading into vesicles despite an ability to enter the cytoplasm.

\section{Loading of other cell types}

To see how general our loading procedure was, we incubated various other cells with high concentrations of DA at room temperature. Figure $3 A$ shows amperometric recording from a pituitary gonadotrope after loading. In these cells, gonadotropinreleasing hormone $(\mathrm{GnRH})$ evokes repetitive oscillations of intracellular $\mathrm{Ca}^{2+}$ and of membrane capacitance increase (Tse et al., 1993). Without a stimulus, the loaded gonadotropes seldom showed amperometric events, but stimulation with $10 \mathrm{~nm} \mathrm{GnRH}$ evoked clear repetitive bursts of secretory events. Gonadotropes that were not loaded with DA showed no amperometric signals $(n=4)$.

We also tested cerebellar granule cells. Without loading, these glutamatergic cells showed no amperometric signals $(n=5)$. 
Loading yielded spontaneous amperometric events seen with an electrode placed on a cell cluster or in a region where many axon terminals converge (Fig. 3B, top and middle traces). Depolarization with $\mathrm{KCl}$ induced a few very large amperometric events, a considerable barrage of small, quantal events, and a broad, slow elevation that may represent unresolved release events from sites more than a few micrometers from the amperometric probe. Perhaps the large events represent large dense-core vesicles and the small events represent exocytosis of small synaptic vesicles. Vesicles of granule cell neurons could also be loaded quickly by fluid-phase endocytosis. This was accomplished by stimulating exocytosis and membrane recycling with high- $\mathrm{K}^{+}$solution for a few minutes in the presence of $70 \mathrm{~mm}$ DA. Recycling vesicles would be expected to bring an aliquot of the DA solution back into the cell. Indeed, subsequent $\mathrm{KCl}$ depolarizations evoked quantal amperometric events repeatedly (Fig. 3B, bottom trace). In repeated depolarizations, full stimulation of DA release occurred when the interval between $\mathrm{KCl}$ depolarizations was $>50$ sec. More frequent stimulation reduced secretion strongly, suggesting depletion of a releasable vesicle pool. There were very few spontaneous events in these fluid-phase loaded cells.

Finally, we tried loading yeast cells because their vesicular secretory pathway is widely studied (Novick et al., 1995). Infrequent amperometric events were detected from DA-loaded yeast spheroplasts $(n=14$; Fig. $3 C)$. The rate of exocytosis increased with the $\mathrm{Ca}^{2+}$ ionophore ionomycin added to the bath, suggesting that exocytosis of at least some loaded vesicles can be stimulated by a $\left[\mathrm{Ca}^{2+}\right]_{\mathrm{i}}$ rise. Individual quantal events from another spheroplast are shown on a faster time scale in the inset (Fig. 3C). Osmotic disruption of the cell with distilled water elicited large amperometric currents with overlapping peaks that might represent release of DA from the cytoplasm and from vesicles. Cells that had not been loaded exhibited neither quantal events nor oxidative currents induced by disruption $(n=6)$.

\section{Loading of PC12 cells containing endogenous catecholamines}

The presence of spontaneous quantal events in AtT-20 and neurons suggested that the DA enters vesicles of both the constitutive and the regulated secretory pathways. This hypothesis was tested in the pheochromocytoma PC12 cell line that synthesizes and stores catecholamines in secretory vesicles and releases them when $\left[\mathrm{Ca}^{2+}\right]_{\mathrm{i}}$ is elevated (Suh and Kim, 1994; Suh et al., 1995). Without previous loading, PC12 cells exhibit quantal release of endogenous catecholamine evoked when cytoplasmic $\left[\mathrm{Ca}^{2+}\right]$ is elevated by brief $\mathrm{KCl}$ depolarization but few spontaneous amperometric events (Fig. $4 A$ ). If our loading procedure loaded only preexisting catecholamine-containing vesicles, the quantal size of evoked events would be increased without changing the frequency of spontaneous, constitutive secretion. However, loading in 70 mM DA increased the spontaneous frequency 10 -fold, while also increasing the frequency and size of KCl-evoked events (Fig. 4B). The $\left[\mathrm{Ca}^{2+}\right]_{\mathrm{i}}$ transient was not changed. Hence, we suggest that exogenous DA accumulates both in preexisting catecholaminecontaining secretory vesicles and in other vesicles that may be part of the constitutive vesicular trafficking.

\section{DISCUSSION}

We demonstrate that with our exogenous loading procedure amperometry can be used to monitor exocytosis. In cells that do not have monoamine transporters, entry into the cytoplasm seems to result from passive diffusion across the plasma membrane as judged by concentration and temperature dependency of loading. Significant entry requires steep concentration gradients across the membrane and works in diverse cell types. From the amount of DA detected by the carbon-fiber electrode upon cell rupture $(5 \pm$ $0.5 \mathrm{amol} / \mathrm{cell} ; n=21 \mathrm{AtT}-20$ cells), we can estimate that cytoplasmic concentrations of DA reached at least $5 \mathrm{~mm}$. All tested

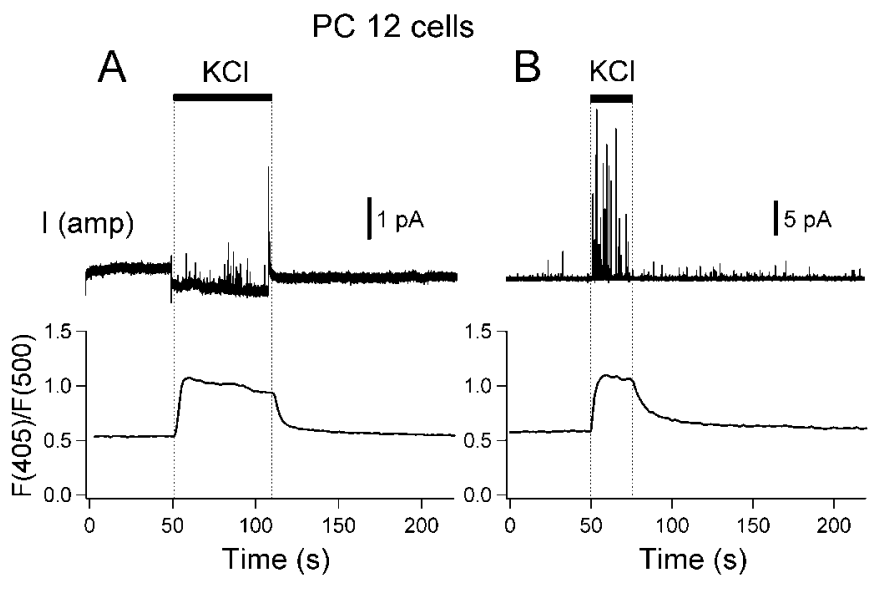

Figure 4. DA loading increased spontaneous and stimulated exocytosis in PC12 cells. $A$, Amperometric signals and $\left[\mathrm{Ca}^{2+}\right]_{i}$ measured simultaneously in an unloaded PC12 cell. This cell was incubated with $1 \mu \mathrm{M}$ indo-1 AM at room temperature for $30 \mathrm{~min}$. $\mathrm{KCl}$ application characteristically produced a small downward offset of a variable size that became smaller with use of the electrode (Zhou and Misler, 1995). B, Another cell was incubated first with $70 \mathrm{~mm}$ DA at room temperature for $30 \mathrm{~min}$, and then with $1 \mu \mathrm{M}$ indo-1 AM for $30 \mathrm{~min}$, and finally amperometric and $\left[\mathrm{Ca}^{2+}\right]_{\mathrm{i}}$ signals were detected. The cells were stimulated with $70 \mathrm{mM} \mathrm{KCl}$ (horizontal bars).

oxidizable amines including DA analogs reached the cytoplasm in high concentrations. Although primarily protonated at physiological $\mathrm{pH}$, each is in equilibrium with a membrane-permeant neutral free-amine form. An inhibitor of DA transporters had no effect on loading, and there is no evidence of saturation for entry at DA concentrations 20,000 times higher than would saturate a DA transporter (Lee et al., 1996).

How do the monoamines enter the secretory compartments during loading? Amines that cross the plasma membrane passively should also cross intracellular membranes but would be trapped if they enter an acidic compartment. We find that millimolar cytoplasmic concentrations favor vesicular loading, and inhibition by bafilomycin shows the necessity of vesicular proton pumping.

We have shown that cells can be loaded without or with stimulation and that amperometric events can be observed without or with stimulation. Tentatively, the unstimulated release might correspond to constitutive exocytosis. Stimulated release may represent regulated exocytosis from a different class of vesicles. It would be valuable to have methods to compare the properties of these two classes of exocytosis. Fluid-phase endocytosis of DA will happen whenever there is membrane recycling with DA in the bath. Its effects should be most pronounced when it is possible to stimulate a heavy round of exocytosis and endocytosis and when the endocytosed vesicles are reused locally rather than cycling through large intracellular compartments that would dilute their contents. These conditions are well met for small synaptic vesicles of stimulated neurons, and we think we have observed this mode of vesicle loading with the cerebellar neurons. Such loading has the advantage of speed and specificity if one wants to focus on small synaptic vesicles. Unlike the unstimulated loading tried in the same neurons, the stimulated loading did not elicit many spontaneous amperometric events that might be because of constitutive exocytosis. Because fluid-phase endocytosis is inevitable when there is exocytosis, it may also contribute to loading of the constitutive secretory compartment during long unstimulated loading. Favorable choice of time, cell type, and stimulation might allow some selectivity in the type of compartment loaded. Although AtT-20 cells divided normally after long exposures to DA, some cell types may be adversely 
affected and many will undergo at least transient responses to the hormone.

With PC12 cells, we were able to compare endogenous secretion to that after further loading with DA. There was a significant increase in the number of spontaneous secretory events, possibly representing loading of vesicles in the constitutive secretory pathway. There also was an increase in the amplitude of stimulated events, presumably representing augmentation of the content of preexisting catecholamine-containing vesicles. A similar increase has been reported when PC12 cells are incubated with $50 \mu \mathrm{M}$ L-DOPA for 40-70 min (Pothos et al., 1996).

In summary, we suggest that these methods may be widely applicable to many types of cells, offering opportunities to characterize spontaneous secretory events in the constitutive pathway as well as stimulus-coupled secretion in the regulated pathway.

\section{REFERENCES}

Alvarez de Toledo G, Fernandez-Chacon R, Fernandez JM (1993) Release of secretory products during transient vesicle fusion. Nature 363:554-558.

Babcock DF, Herrington J, Goodwin PC, Park YB, Hille B (1997) Mitochondrial participation in the intracellular $\mathrm{Ca}^{2+}$ network. J Cell Biol 136:833-844.

Billiard J, Koh DS, Babcock DF, Hille B (1997) Protein kinase C as a signal for exocytosis. Proc Natl Acad Sci USA 94:12192-12197.

Bowman EJ, Siebers A, Altendorf K (1988) Bafilomycins: a class of inhibitors of membrane ATPases from microorganisms, animal cells, and plant cells. Proc Natl Acad Sci USA 85:7972-7976.

Chien JB, Wallingford RA, Ewing AG (1990) Estimation of free dopamine in the cytoplasm of the giant dopamine cell of Planorbis corneus by voltammetry and capillary electrophoresis. J Neurochem 54:633-638.

Chow RH, von Rüden L (1995) Electrochemical detection of secretion from single cells. In: Single-channel recording (Sakmann B, Neher E, eds), pp 245-275. New York: Plenum.

Chow RH, von Rüden L, Neher E (1992) Delay in vesicle fusion revealed by electrochemical monitoring of single secretory events in adrenal chromaffin cells. Nature 356:60-63.

Dersch CM, Akunne HC, Partilla JS, Char GU, de Costa BR, Rice KC, Carroll FI, Rothman RB (1994) Studies of the biogenic amine transporters. 1. Dopamine reuptake blockers inhibit $\left[{ }^{3} \mathrm{H}\right]$ mazindol binding to the dopamine transporter by a competitive mechanism: preliminary evidence for different binding domains. Neurochem Res 19:201-208.

Dunn B, Wobbe CR (1997) Preparation of protein extracts from yeast. In: Current protocols in molecular biology (Ausubel FM, Brent R, Kingston RE, Moore DD, Seidman JG, Smith JA, Struhl K, eds), Unit 13.3. New York: Wiley.
Eshleman AJ, Henningsen RA, Neve KA, Janowsky A (1994) Release of dopamine via the human transporter. Mol Pharmacol 45:312-316.

Gumbiner B, Kelly RB (1981) Secretory granules of an anterior pituitary cell line, AtT-20, contain only mature forms of corticotropin and $\beta$-lipotropin. Proc Natl Acad Sci USA 78:318-322.

Koh DS, Hille B (1999) Rapid fabrication of plastic-insulated carbonfiber electrodes for micro-amperometry. J Neurosci Methods 88:83-91.

Koh DS, Moody MW, Nguyen TD, Hille B (2000) Regulation of exocytosis by protein kinases and $\mathrm{Ca}^{2+}$ in pancreatic duct epithelial cells. $\mathrm{J}$ Gen Physiol, in press.

Lee FJ, Pristupa ZB, Ciliax BJ, Levey AI, Niznik HB (1996) The dopamine transporter carboxyl-terminal tail. Truncation/substitution mutants selectively confer high affinity dopamine uptake while attenuating recognition of the ligand binding domain. J Biol Chem 271:20885-20894.

Leszczyszyn DJ, Jankowski JA, Viveros OH, Diliberto Jr EJ, Near JA, Wightman RM (1991) Secretion of catecholamines from individual adrenal medullary chromaffin cells. J Neurochem 56:1855-1863.

Novick P, Garrett MD, Brennwald P, Lauring A, Finger FP, Collins R, Terbush DR (1995) Control of exocytosis in yeast. Cold Spring Harb Symp Quant Biol 60:171-177.

Pothos E, Desmond M, Sulzer D (1996) L-3,4-dihydroxyphenylalanine increases the quantal size of exocytotic dopamine release in vivo. J Neurochem 66:629-636.

Suaud-Chagny MF, Dugast C, Chergui K, Msghina M, Gonon F (1995) Uptake of dopamine released by impulse flow in the rat mesolimbic and striatal systems in vitro. J Neurochem 65:2603-2611.

Suh BC, Kim KT (1994) Inhibition by ethaverine of catecholamine secretion through blocking L-type $\mathrm{Ca}^{2+}$ channel in PC12 cells. Biochem Pharmacol 47:1262-1266.

Suh BC, Lee CO, Kim KT (1995) Signal flows from two phospholipase $\mathrm{C}$-linked receptors are independent in PC12 cells. J Neurochem 64:1071-1079.

Schulz JB, Weller M, Klockgether T (1996) Potassium deprivationinduced apoptosis of cerebellar granule neurons: a sequential requirement for new mRNA and protein synthesis, ICE-like protease activity, and reactive oxygen species. J Neurosci 16:4696-4706.

Tse A, Tse FW, Almers W, Hille B (1993) Rhythmic exocytosis stimulated by GnRH-induced calcium oscillations in rat gonadotropes. Science 260:82-84

Wightman RM, Jankowski JA, Kennedy RT, Kawagoe KT, Schroeder TJ, Leszczyszyn DJ, Near JA, Diliberto Jr EJ, Viveros OH (1991) Temporally resolved catecholamine spikes correspond to single vesicle release from individual chromaffin cells. Proc Natl Acad Sci USA 88:10754-10758.

Zhou Z, Misler S (1995) Amperometric detection of stimulus-induced quantal release of catecholamines from cultured superior cervical ganglion neurons. Proc Natl Acad Sci USA 92:6938-6942.

Zhou Z, Misler S (1996) Amperometric detection of quantal secretion from patch-clamped rat pancreatic $\beta$-cells. J Biol Chem 271:270-277. 